\title{
Trophic ecology of Hemigrammus marginatus Ellis, 1911 (Characiformes, Characidae) in a conserved tropical stream
}

\author{
E. N. Fragoso-Moura ${ }^{*}$, T. F. Luiz ${ }^{a}$, R. Z. Coeti ${ }^{a}$ and A. C. Peret ${ }^{a}$ \\ a'Laboratório de Dinâmica de Populações, Programa de Pós-graduação em Ecologia e Recursos Naturais - PPGERN, \\ Departamento de Hidrobiologia, Universidade Federal de São Carlos - UFSCar, Rodovia Washington Luís, SP-310, \\ Km 235, CEP 13565-905, São Carlos, SP, Brazil \\ *e-mail: evelise@ufscar.br
}

Received: October 7, 2015 - Accepted: February 29, 2016 - Distributed: May 31, 2017

(With 6 figures)

\begin{abstract}
The trophic ecology of ichthyofauna in a stream can be related to the presence or absence of riparian and aquatic vegetation, and mainly resource availability. Therefore, the aim of this study was to analyse the seasonal and ontogenetic variations for the trophic ecology of Hemigrammus marginatus in the Beija-Flor stream located at the Jataí Ecological Station in the municipality of Luiz Antônio-SP, Brazil. In order to attain this objective, the data collections were carried out on a monthly basis from August, 2011 to July, 2012. Fish were collected using a trawl net and bait traps from three collection stations distributed along the Beija-Flor stream. The quality of the water was evaluated by the chemical variables: ammonia, nitrate, total nitrogen, total phosphorus, and physical temperature, dissolved oxygen, $\mathrm{pH}$, turbidity and conductivity, obtained by using a Yellow Springs sonde. The collected specimens were fixed in $10 \%$ formalin in the field and were subjected to biometric measurements in the laboratory. The stomachs were weighed and transferred to $70 \%$ alcohol and the stomach contents were analysed using a stereomicroscope at the lowest possible taxonomic level. The species was considered insectivorous and the autochthonous food items were the most important during the dry season, mainly from the orders Ephemeroptera and Trichoptera, while allochthonous items from the order Hymenoptera were more important in the wet season. The young individuals' diet was based on the consumption of zooplankton, and insofar as the fish develops, there was a decrease in this item in the diet showing that the species has ontogenetic shifts in its diet. The conservation state of the Beija-Flor stream, as well as the flexibility of using food and food resources provided by aquatic macrophytes and riparian vegetation are key factors for the high abundance of the H. marginatus species.
\end{abstract}

Keywords: stream fish, diet, ontogenetic variations, riparian vegetation, upper Paraná basin, seasonality.

\section{Ecologia trófica do Hemigrammus marginatus Ellis, 1911 (Characiformes, Characidae) em um riacho tropical conservado}

\begin{abstract}
Resumo
A ecologia trófica da ictiofauna em um riacho pode estar relacionada à presença ou ausência de mata ciliar e vegetação aquática, e principalmente pela disponibilidade de recursos no ambiente. Assim, o objetivo deste estudo foi analisar as variações sazonais e ontogenéticas na ecologia trófica de Hemigrammus marginatus no córrego Beija-Flor, localizado na Estação Ecológica de Jataí, localizada no município de Luiz Antônio-SP, Brasil. Para atender esse objetivo as coletas de dados foram realizadas mensalmente no período de agosto de 2011 a julho de 2012. Os peixes foram coletados utilizando rede de arrasto e armadilhas iscadas, em três estações de coleta distribuídas ao longo do córrego Beija-Flor. A qualidade da água foi avaliada pelas variáveis químicas amônia, nitrato, nitrogênio total, fósforo total, e físicas temperatura, oxigênio dissolvido, $\mathrm{pH}$, turbidez e condutividade, obtidas com auxilio de uma sonda Yellow Springs. Os espécimes coletados foram fixados em formalina a $10 \%$ no campo e em laboratório foram submetidos a medidas biométricas. Os estômagos foram pesados e transferidos para álcool a 70\%, e o conteúdo estomacal analisado em estereomicroscópio até o menor nível taxonômico possível. A espécie foi considerada insetívora, sendo os itens alimentares de origem autóctone de maior importância no período de seca, principalmente das ordens Ephemeroptera e Trichoptera, enquanto os itens de origem alóctone, da ordem Hymenoptera, tiveram maior importância no período de cheia. A dieta dos indivíduos jovens foi baseada no consumo de zooplâncton, à medida que os peixes se desenvolvem/ crescem ocorre uma diminuição deste item na dieta, evidenciando que a espécie possui variações ontogenéticas na sua dieta. O estado de conservação do córrego Beija-Flor, associado à flexibilidade no uso do alimento e os recursos alimentares proporcionadas pelas macrófitas aquáticas e mata ciliar são fatores fundamentais para a elevada abundância da espécie H. marginatus.
\end{abstract}

Palavras-chave: peixes de riacho, dieta, variações ontogenéticas, vegetação ripária, bacia do alto rio Paraná, sazonalidade. 


\section{Introduction}

Changes in fish diet in neotropical streams may be related to seasonal and environmental variations (Lowe-McConnell, 1987; Wootton, 1992; Abelha et al., 2001). Food resources originating from riparian vegetation play a major role in the fish diet, mainly in the wet season (Lowe-McConnell, 1987; Abilhoa et al., 2008, 2010). Another important factor is the presence of macrophytes because they provide habitats that can influence the composition of the associated fauna and the interspecific relationships of the species in aquatic ecosystems (Thomas et al., 2010). According to Pelicice et al. (2005), aquatic macrophytes provide places for shelter, food and refuge for small fish and invertebrates. The ichthyofauna associated with macrophyte banks, which can be found along the coastal area of lakes and streams, mainly consists of species of small characins, which benefit from the availability of food from this micro-habitat (Rozas and Odum, 1988; Delariva et al., 1994; Suarez et al., 2007).

Changes in the fish diet may also be related to the individual's size, the position of the mouth, the size of the digestive tract, and the ability to move and capture food resources in the environment (Wootton, 1998; Vitule et al., 2008). Ontogenetic variations in the diet during growth is a way to expand or change the niche of the species in order to avoid inter and intra-specific competition and maintain the shared resources (Bonato and Fialho, 2014). According to Cassemiro et al. (2008), fish species with food plasticity have weak ontogenetic changes and a slight expansion in the niche breadth. They are unlike piscivorous fish, which have a diet based on benthic organisms when young and become experts when adults (Cassemiro et al., 2008). However, ontogenetic studies using fish with insectivore feeding behavior are scarce.

Hemigrammus marginatus Ellis 1911 is a small characid known in Brazil as "red-tailed flag", commonly found in streams, rivers and lakes in the basins of the Guaporé, Amazonas, Itapicuru, Orinoco, São Francisco, Paraná and Paraguai rivers (Lima et al., 2003; Reis et al., 2005). Some studies show that this species prefers lotic environments, but is commonly found in lentic environments, and can be considered insectivorous (Agostinho et al., 1997; Casatti et al., 2003). In this context, the aim of this study is to analyze seasonal and ontogenetic variations in the trophic ecology of Hemigrammus marginatus in the Beija-Flor stream, located at the Jataí Ecological Station, Luiz Antônio-SP.

\section{Material and Methods}

\subsection{Characterization of the study area}

The Jataí Ecological Station (Figure 1) consists of three main types of ecosystems: the Mogi-Guaçu river, streams, swamps and marginal lagoons; the flooded land areas separating the lakes from the river and the terrestrial

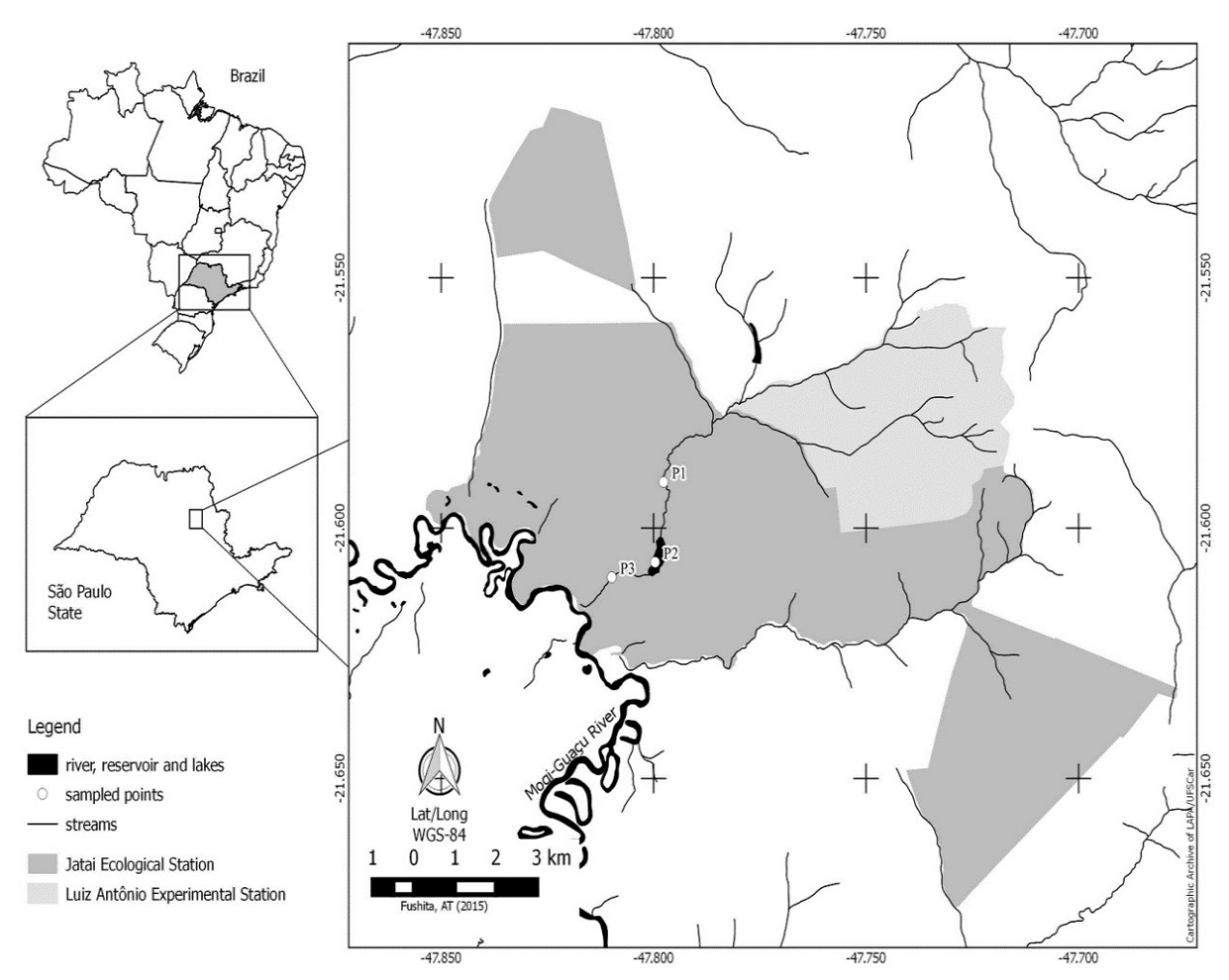

Figure 1. Location of the Jataí Ecological Station (Luiz Antônio, SP, Brazil), showing the Mogi-Guaçu river and collection stations: 1 - Beija-Flor stream upstream from the dam, 2 - Beija-Flor reservoir and 3 - Beija-flor stream downstream from the dam. 
ecosystems, consisting of savannah areas (Santos et al., 1989; Pires, 1994). There are two distinct climatic periods: from November to April, when temperatures and rainfall are high; and from May to October, when temperatures and rainfall are low (Santos et al., 1989).

The Beija-Flor stream is $13.95 \mathrm{~km}$ long (Pires, 1994), and is formed by the waters of the Bandeira, Jordão and Cabaças stream and flows into the Mogi-Guaçu river (Figure 1). Its substrate is sandy, and it is bordered by healthy riparian vegetation and aquatic macrophytes along its entire length and stretches with different current speeds, as well as pools in some places.

The Beija-Flor reservoir is a disused clay pit turned into a permanent floodplain of 17.54 hectares and an average depth of $1.80 \mathrm{~m}$; it has healthy riparian vegetation and aquatic macrophytes, and is located 300 meters from the mouth of the Beija-Flor stream. It does not have any kind of dam, and maintains ongoing communication with the Mogi-Guaçu river through this stream, which may function as a corridor for fish between the reservoir and the river. It was flooded in 1965 and there are no previous ecological studies of the clay pit (Rodrigues, 1997).

\subsection{Water and fish samples}

The water and $H$. marginatus samples were collected monthly from August, 2011 to July, 2012 in three collection stations (Figure 1). Collection station 1 ( $47^{\circ} 47^{\prime} 50.208^{\prime}$ 'W, $21^{\circ} 35^{\prime} 25.08^{\prime}$ 'S) has riparian vegetation of the gallery forest type with substrate or a sandy bed, and in $60 \%$ of this stretch, macrophytes were found rooted to its banks. Collection station 2 ( $47^{\circ} 48^{\prime} 52.808^{\prime}$ 'W, $21^{\circ} 36$ ' 33.552” S), where the highest concentration of species was found, is located in the Beija-Flor reservoir, it has a muddy bottom with large banks of rooted and floating aquatic macrophytes, and about $80-90 \%$ of the sample stretch was covered with aquatic macrophytes. Collection station $3\left(47^{\circ} 48^{\prime} 34.02^{\prime}\right.$ 'W, $21^{\circ} 36$ ' 33.624" S) has areas of flows and pools, and pebbles on the riverbed. The riparian vegetation is of the gallery forest type and has many tree roots on the banks. It has floating and rooted aquatic macrophytes which can be found in about $50 \%$ of the river banks.

The samples were collected using transparent acrylic bait traps with openings of $3 \mathrm{~cm}, 6 \mathrm{~cm}$ and $9 \mathrm{~cm}$ and a trawl net with a mesh size of $1 \mathrm{~cm}$. The collection using a trawl net was done over a distance of $15 \mathrm{~m}$ on the banks of each collection station of the Beija-Flor stream. The fish were anaesthetized using a clove oil solution fixed in $10 \%$ formalin and after 48 hours they were transferred to $70 \%$ alcohol.
In the Population Dynamics Laboratory at the Department of Hydrobiology at the Federal University of São Carlos, fish were subjected to biometric measurements to obtain data of the standard and total lengths (in millimeters), using a $1 \mathrm{~mm}$ precision icterometer and were dissected. The total weight of the fish was obtained using a Gehaka BG 1000 precision balance with a precision of $0.01 \mathrm{~g}$ and the stomach weight was obtained using the Scientech SA-210 balance with a precision of $0.0001 \mathrm{~g}$. After weighing, the stomachs were placed in vials containing $70 \%$ alcohol for further analysis. Stomach repletion was determined by assigning values on a scale from 1 to 3 (from empty to completely full), and only the stomachs with repletion degrees of 2 and 3 were analyzed. Some food resources found in the stomachs could not be identified due to the high degree of decomposition and were grouped in the item "Others".

The determination of the first gonadal maturation size of $H$. marginatus in the Beija-Flor stream followed the methodology of Sato and Godinho (1988), which considers the size of the smallest individual found in advanced maturation, and this size was used to divide the fish into standard length classes, separating them into young and adults. In this study, the male and female samples with a standard length of $1.8 \mathrm{~cm}$ were considered young, and above this length were considered adults. Standard length class 1 includes individuals which measure 1.4 to $1.8 \mathrm{~cm}$; class 2 from 1.9 to $2.3 \mathrm{~cm}$; class 3 from 2.4 to $2.8 \mathrm{~cm}$; class 4 from 2.9 to $3.3 \mathrm{~cm}$ and class 5 from 3.4 to $4.0 \mathrm{~cm}$.

Voucher specimens of $H$. marginatus were deposited in the collection at the São Paulo State University, São José do Rio Preto campus-SP, Brazil, under number 17502.

Water samples were collected using a Van Dorn bottle. The physical and chemical parameters were obtained using the methods described in Table 1.

\subsection{Data analysis}

The water quality was established by interpreting the results found by analysing the main components, as in Legendre and Legendre (2012), to characterize them according to the most important variables in the dry and wet seasons.

Identified food items at the lowest taxonomic level was used to characterize the diet. The diet analysis was based on the frequency of the occurrence method (Fi), which is the number of times a particular food item is found (Hynes, 1950), and the volumetric method (Vi), in which the volume of each food item was obtained from a battery of graduated cylinders (Hyslop, 1980). The importance of

Table 1. Methodology used to analyse water collected from the Beija-Flor stream at the Jataí Ecological Station (Luiz Antônio, SP, Brazil) from August, 2011 to July, 2012.

\begin{tabular}{ll}
\hline \multicolumn{1}{c}{ Variable analysed } & Method \\
\hline $\begin{array}{l}\text { Temperature, pH, Electrical Conductivity, Dissolved } \\
\text { Oxygen, Turbidity }\end{array}$ & Yellow Springs Multiparameter sonde 6820 - V2 \\
Ammonia ${ }^{1}$, Total Organic Nitrogen ${ }^{2}$, Nitrate $^{2}$, Nitrite $^{2}$, & Spectrophotometer \\
Total Phosphorus & \\
\hline${ }^{1}$ Koroleff (1976), ${ }^{2}$ Mackereth et al. (1978), ${ }^{3}$ Murphy and Riley (1962).
\end{tabular}


each item was attributed according to the number of times they were found and their volume. This data comprises the Alimentary Index (AIi) proposed by Kawakami and Vazzoler (1980), which is determined in accordance with the mathematical formula below (Equation 1):

$$
A I_{i}=\frac{F_{i} \cdot V_{i}}{\sum_{i=1}^{n}\left(F_{i} \cdot V_{i}\right)}
$$

where: $A I_{i}=$ Alimentary Index; $i=1,2, \ldots \mathrm{n}=$ particular food item; $F_{i}=$ frequency of occurrence $(\%)$ of each item; $V_{i}=$ Volume $(\%)$ of each item.

Cluster analysis, using the Bray-Curtis similarity coefficient, was used to show the similarity between the food items distributed in the $H$. marginatus size classes. This index ranges from 0 to 1 and has been recommended due to its consistency in biological analyses (Tabachnick and Fidell, 1996). The cophenetic correlation coefficient is included with the cluster analysis result to reflect the degree of distortion caused by the construction of the dendrogram, i.e. the lowest degree of distortion will be reflected by the highest cophenetic coefficient (Legendre and Legendre, 2012). A complementary analysis of canonical discriminant functions was used to observe the relationship between dry and wet seasons with food items found in $H$. marginatus stomachs.

\section{Results}

The variables responsible for the F1 axis ordination were nitrate, nitrite, turbidity, ammonia and total phosphorus, which characterize the increase in the organic matter dissolved in the dry and wet seasons in the Beija-Flor stream (Figure 2). On the F2 axis, the variation was assigned to the variables of dissolved oxygen, $\mathrm{pH}$, total nitrogen and electrical conductivity, which characterize the dry season of the Beija-Flor stream (Figure 2). The temperature ranged from $18{ }^{\circ} \mathrm{C}$ to $31.2{ }^{\circ} \mathrm{C}$ during the wet season, and from $12.8^{\circ} \mathrm{C}$ to $29.3^{\circ} \mathrm{C}$ during the dry season.

The total number of $H$. marginatus samples collected was $1,126.00$ of which 38 young specimens and 256 adult specimens were used to analyse the stomach contents; 98 with degree of repletion 2 and 196 with a degree of repletion 3 . The classes of lengths 2, 3 and 4 presented the highest number of individuals, and consequently more stomachs within these classes were analysed. Insects were the main food source for the H. marginatus specimens, corresponding to $92 \%$ of the total number of items, showing that its eating habits are predominantly insectivore.

Zooplankton was found in higher amounts in the H. marginatus diet only in length 1 class, which consists of young individuals. As the specimens grew, there was less zooplankton in the H. marginatus diet. However, other items became more important, such as Diptera, Ephemeroptera, Trichoptera and Hymenoptera larvae and pupae. The items which were more consumed by the species (Ephemeroptera, Trichoptera and Hymenoptera) occurred in different proportions in all the length classes (Figure 3). Moreover, plant tissues (pollen and seeds) and fish scales were found less in the diet (Figure 3). The most frequent food items were Diptera, Ephemeroptera, Trichoptera, Coleoptera larvae (Staphylinidae) and Hymenoptera during the dry season, while the items Ephemeroptera, Hymenoptera

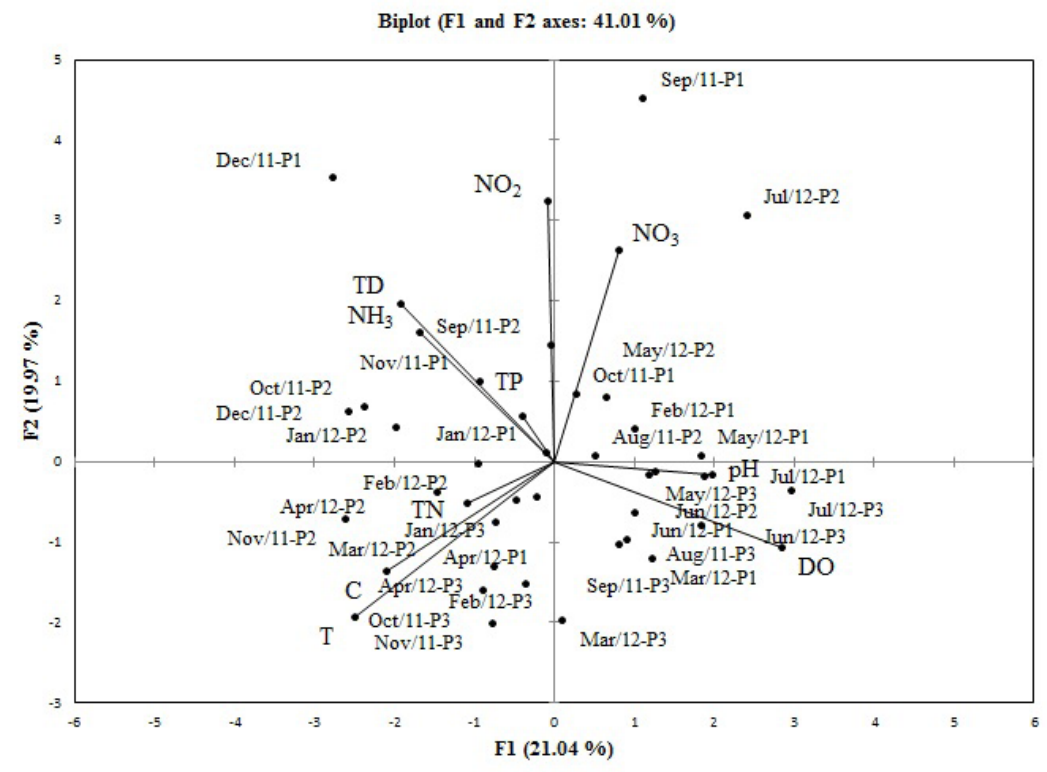

Figure 2. Analysis of the main components of the water's physical and chemical variables in the Beija-Flor stream, located at the Jatai Ecological Station, Luiz Antônio - SP, Brazil. Captions: pH - hydrogenionic potential, DO - dissolved oxygen, $\mathrm{NO}_{2}$ - nitrate, $\mathrm{NO}_{3}$ - nitrite, $\mathrm{TD}$ - turbidity, $\mathrm{C}$ - electrical conductivity, $\mathrm{TP}$ - total phosphorus, $\mathrm{T}$ - water temperature, $\mathrm{TN}$ - total nitrogen, $\mathrm{NH}_{3}-$ ammonia, collection stations: P1, P2 and P3. 
and Trichoptera were more often found during the wet season (Table 2). The items classified as "other" could not be identified, due to their high level of decomposition. Among the order Hymenoptera, ants were the items that were more often found in the $H$. maginatus diet.
The Bray-Curtis Similarity Dendrogram, using the AIi, showed a main cluster between the classes of 2, 3 and 4 lengths, due to similarities between the food items found in the diet of the individuals (Figure 4). The class of length 1 remained in a separate group owing

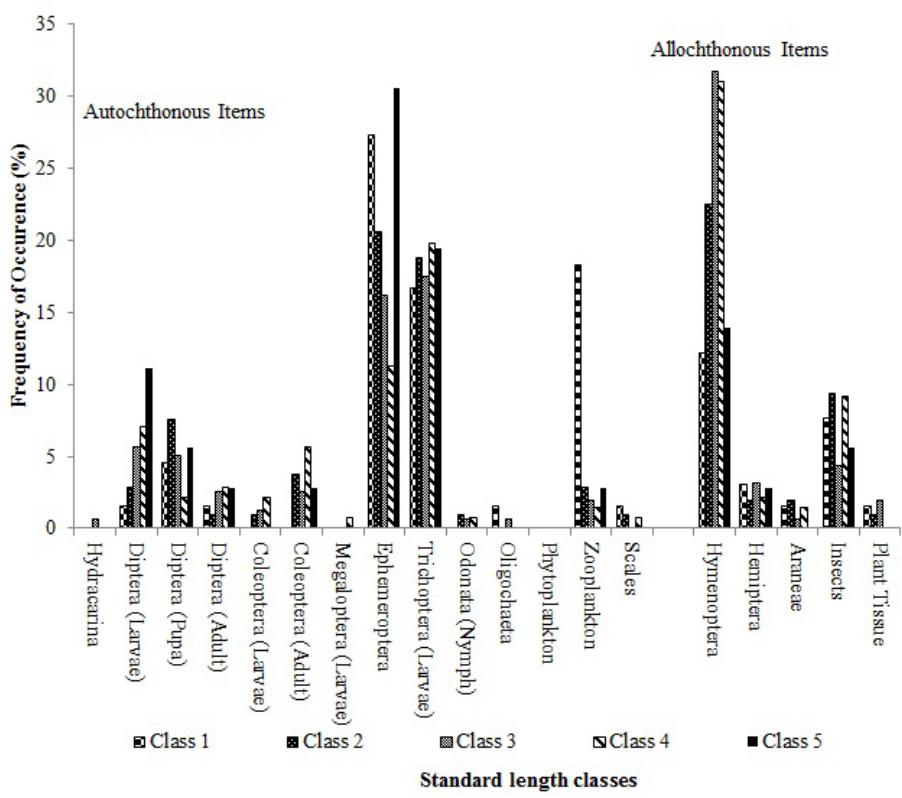

Figure 3. Frequency of Occurrence of food items distributed in the standard length classes (cm) of the Hemigrammus marginatus species, collected at the Beija-Flor stream, located at the Jatai Ecological Station, Luiz Antônio - SP, Brazil.

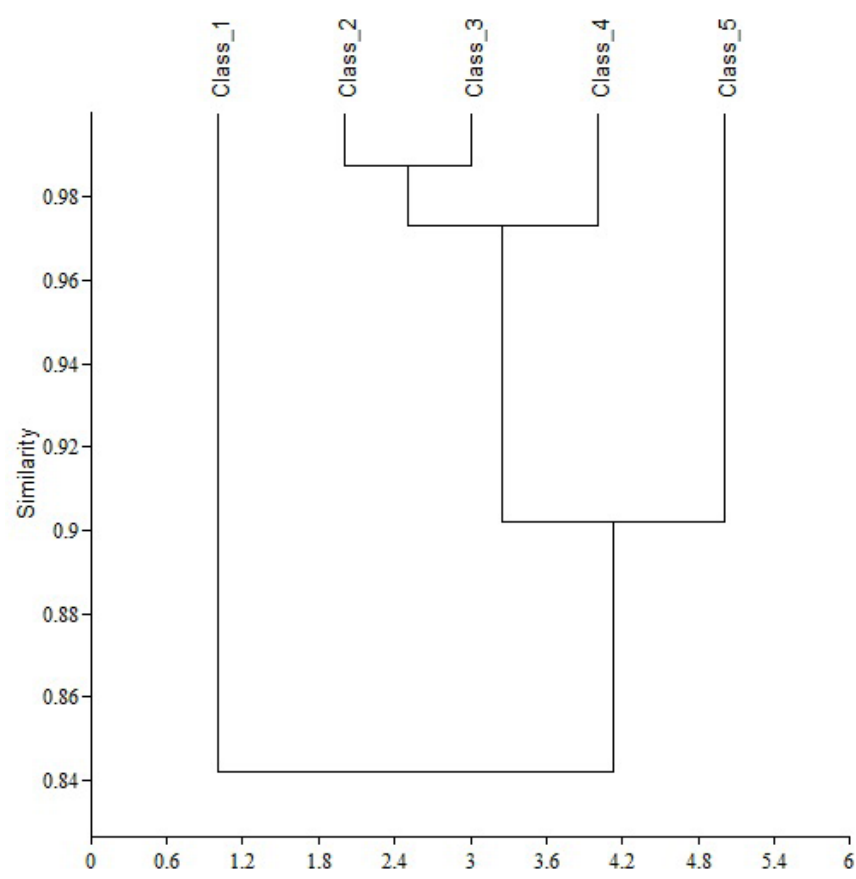

Figure 4. Similarity Dendrogram (with numbers obtained from the Alimentary Index - AIi), using Bray-Curtis, of food items distributed in the standard length classes of the Hemigrammus marginatus in the Beija-Flor stream, located at the Jatai Ecological Station (Luiz Antônio-SP). Cophenetic Coefficent 0.976. 
Table 2. Frequency of Occurence and Alimentary Index (AIi) of the food items consumed during the dry and wet seasons by the Hemigrammus marginatus species in the Beija-Flor stream, located at the Jatai Ecological Station, Luiz Antônio - SP, Brazil.

\begin{tabular}{|c|c|c|c|c|c|c|}
\hline Food Items & V\%Dry & V\%Wet & FO\%Dry & FO\%Wet & AIiDry & AliWet \\
\hline \multicolumn{7}{|l|}{ Insect } \\
\hline Fragments of insects & 6.4373 & 14.6182 & 17.5 & 11.5538 & 0.0220 & 0.0459 \\
\hline \multicolumn{7}{|l|}{ Coleoptera } \\
\hline Staphylinidae (larvae) & 6.8812 & 0.0024 & 40 & 0.7968 & 0.0538 & $<0.0001$ \\
\hline Carabidae & 1.7758 & 0.9314 & 5 & 5.9761 & 0.0017 & 0.0015 \\
\hline Coleoptera (larvae) & 1.1099 & 0.5951 & 2.5 & 0.7968 & 0.0005 & 0.0001 \\
\hline Psephenidae (larvae) & 0 & 0.0129 & 0 & 0.3984 & 0 & $<0.0001$ \\
\hline Dryopidae (larvae) & 0 & $<0.0001$ & 0 & 0.3984 & 0 & $<0.0001$ \\
\hline \multicolumn{7}{|l|}{ Diptera } \\
\hline Diptera & 1.9978 & 1.0220 & 25 & 11.5538 & 0.0003 & 0.0016 \\
\hline Chironomidae (larvae) & 0.2220 & 0.9600 & 2.5 & 5.9761 & 0.0001 & 0.0016 \\
\hline Ceratopogonidae (larvae) & 0.2220 & 0.0776 & 2.5 & 1.5936 & 0.0001 & $<0.0001$ \\
\hline Simuliidae (larvae) & 0 & 0.1294 & 0 & 1.5936 & 0 & 0.0001 \\
\hline Dixidae (larvae) & 0 & 0.0259 & 0 & 0.3984 & 0 & $<0.0001$ \\
\hline Megaloptera (larvae) & 0 & 0.0517 & 0 & 0.3984 & 0 & $<0.0001$ \\
\hline Ephemeroptera & 37.4029 & 9.2496 & 55 & 28.2869 & 0.4020 & 0.0711 \\
\hline \multicolumn{7}{|l|}{ Hemiptera } \\
\hline Hemiptera & 0.8879 & 0.9314 & 5 & 4.7809 & 0.0009 & 0.0010 \\
\hline Notonecta $\mathrm{sp}$. & 0.2220 & 0.0517 & 2.5 & 0.7968 & 0.0001 & $<0.0001$ \\
\hline Trichoptera (larvae) & 11.0988 & 6.6343 & 200 & 31.0757 & 0.4338 & 0.0560 \\
\hline \multicolumn{7}{|l|}{ Hymenoptera } \\
\hline Formicidae & 20.5327 & 61.4739 & 20 & 49.0040 & 0.0670 & 0.8183 \\
\hline Apidae & 0.4440 & 1.1902 & 2.5 & 0.7968 & 0.0002 & 0.0003 \\
\hline Odonata (nymph) & 0 & 0.1552 & 0 & 1.1952 & 0 & 0.0001 \\
\hline \multicolumn{7}{|l|}{ Arachnida } \\
\hline Araneae & 0.2220 & 0.2329 & 2.5 & 1.9920 & 0.0001 & 0.0001 \\
\hline Hydracarina & 0 & 0.0259 & 0 & 0.3984 & 0 & $<0.0001$ \\
\hline \multicolumn{7}{|l|}{ Zooplankton } \\
\hline Daphnia sp. & 0.3330 & 1.4155 & 5 & 5.9761 & 0.0003 & 0.0023 \\
\hline Copepoda & 0.8879 & 0.0129 & 2.5 & 0.3984 & 0.0004 & $<0.0001$ \\
\hline Conchostraca & 0 & 0.0014 & 0 & 0.3984 & 0 & $<0.0001$ \\
\hline Oligochaeta & $<0.0001$ & 0.0323 & 2.5 & 0.7968 & $\mathrm{X}$ & $<0.0001$ \\
\hline \multicolumn{7}{|l|}{ Fish } \\
\hline Scales & 0 & 0.0572 & 0 & 1.1952 & 0 & $<0.0001$ \\
\hline \multicolumn{7}{|l|}{ Plant Tissue } \\
\hline Alga filamentosa & 0.2220 & 0.0259 & 2.5 & 0.3984 & 0.0001 & $<0.0001$ \\
\hline Seeds & 0 & 0.0184 & 0 & 0.7968 & 0 & $<0.0001$ \\
\hline Pollen & 0 & 0.0259 & 0 & 0.3984 & 0 & $<0.0001$ \\
\hline Other & 9.1010 & 0.0388 & 5 & 0.7968 & 0.0089 & $<0.0001$ \\
\hline Total & 100 & 100 & 400 & 170.9163 & 1 & 1 \\
\hline
\end{tabular}

to the fact that the individuals had a higher amount of zooplankton in their diet, which shows evidence that the $H$. marginatus has ontogenetic variations in their diet. The class of length 5 formed another group of individuals, because this class did not present any plant origin items in their diet (Figure 4).

The Discriminant Analysis showed differences concerning the items found only at collection station 3 due to the dry and wet periods. At this station, during the dry season, the $H$. marginatus consumed a higher amount of autochthonous food items, mainly Ephemeroptera and Trichoptera and, during the wet season, most of the items consumed were allochthonous, composed by Hymenoptera, mainly ants. In collection stations 1 and 3 , which had similar characteristics (Figure 5) concerning the environment and the type of food items (Ephemeroptera and Trichoptera), it was observed that they were different only at station 2 in the wet season. 
Considering the Alimentary Index values, the allochthonous items had the highest values during the wet season compared to the dry season $(\mathrm{AI} i=0.8660$ and AIi- 0.0776, respectively). The Alimentary Index of the autochthonous items was 0.9096 during the dry season and 0.1798 during the wet season (Figure 6). The Alimentary Index value for the Hymenoptera item was higher during the wet season $(\mathrm{AI}=0.8183)$. The autochthonous items (Ephemeroptera and Trichoptera) were more important during the dry season $(\mathrm{AIi}=0.4020$ and $\mathrm{AIi}=0.4338$, respectively) (Table 2$)$.

\section{Discussion}

The Beija-Flor stream did not show high variations in the physical and chemical parameters of the water. The temporal variation of its dynamics was observed, mainly because of the increase in temperature and rainfall in the wet season months. Due to the increase in the rainfall, there was an increase in the variables - nitrate, nitrite, turbidity and electrical conductivity. In this period, the highest rainfall increases the volume of rivers, which usually increases the transportation of organic material

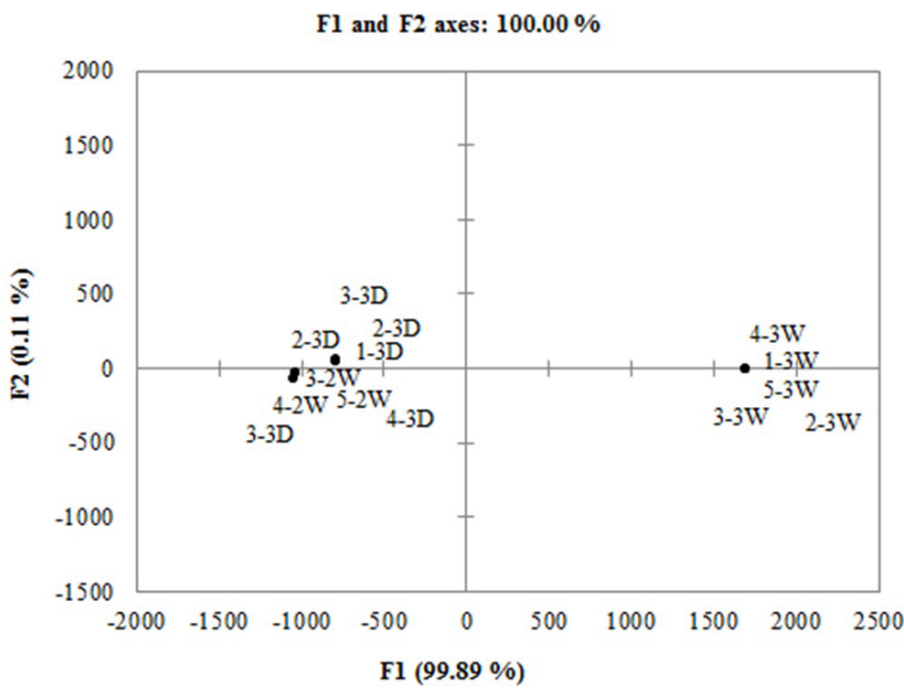

Figure 5. Discriminant analysis, based on the Alimentary Index (AIi) of the Hemigrammus marginatus species food items distributed in the standard length classes 1, 2, 34 and 5, collected at stations 1, 2 and 3 during the dry seasons (D) and wet seasons (W) in the Beija-Flor stream, Jatai Ecological Station (Luiz Antônio-SP, Brazil).

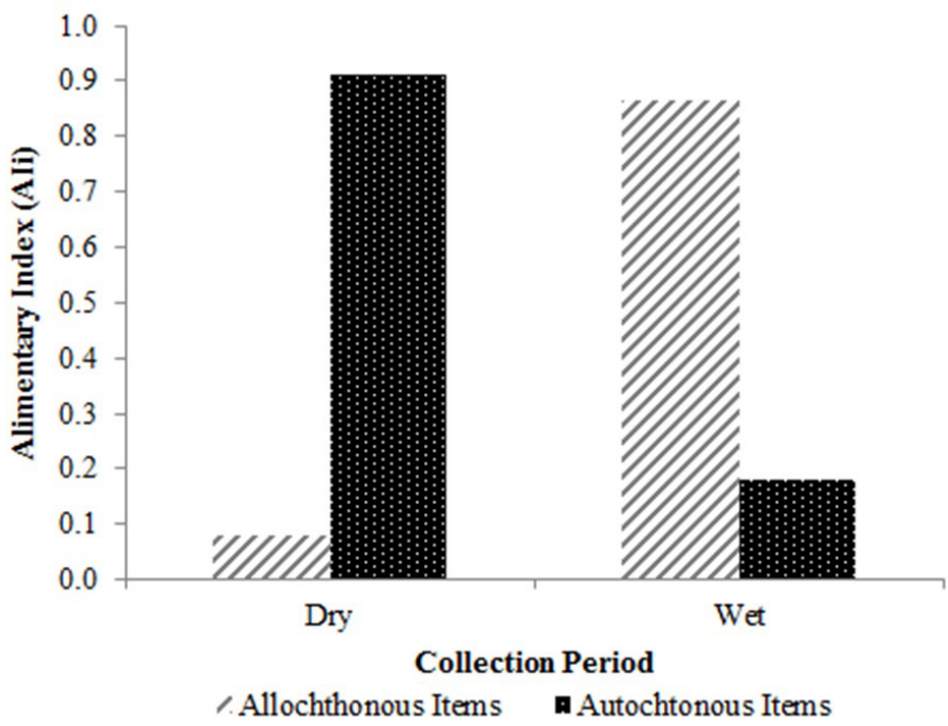

Figure 6. Alimentary Index (AIi) of the allochthonous and autochthonous food items considering all the standard length classes of the Hemigrammus marginatus species in the dry and wet seasons in the Beija-Flor stream, located at Jatai Ecological Station, Luiz Antônio-SP, Brazil. 
and insects, which are important for feeding small fish (Wetzel and Likens, 2005).

Hemigrammus marginatus has an omnivorous habit in different environments (Casatti and Castro, 1998; Graciolli et al., 2003). In the Beija-Flor stream, insects made up the largest proportion of the diet in all the standard length classes. It can be inferred that these arthropods, especially the orders Ephemeroptera, Hymenoptera and Trichoptera, support the high density of these fish. Young individuals of the first standard length class consumed a large amount of zooplankton. The ontogenetic variations in freshwater fish diet have been commonly reported in the literature (Hahn et al., 2000; Lima-Junior and Goitein, 2003; Cassemiro et al. 2008; Mazzoni and Costa, 2007; Agostinho et al., 2009; Suiberto et al., 2009; Abilhoa et al., 2010; Lima and Behr, 2010; Mazzoni et al., 2010; Bonato and Fialho, 2014). The ontogenetic variations found in the H. marginatus diet in the Beija-Flor stream are determined by the size of the fish, prey and ease of predation of available food resources, as the fish become adults, predation by the zooplankton item undergoes a significant decrease.

Hemigrammus marginatus feed on autochthonous items in the dry season. However, terrestrial insects, especially the order Hymenoptera, were found in the two collection periods which is a staple food in the wet season. In her study on the Rosana Reservoir, in the Paranapanema River, Casatti et al. (2003) classified the H. marginatus species as invertivorous as its diet is based on autochthonous food, especially pupae and larvae of chironomids in the dry and wet seasons. In a study in the same reservoir, Pelicice and Agostinho (2006) found that the $H$. marginatus species fed mainly on autochthonous items, zooplankton was a significant part of the diet and larvae of aquatic insects and terrestrial insects were consumed in smaller quantities. The diet of $H$. marginatus in a stream in the municipality of Ivinhema, Mato Grosso do Sul consisted of insects as the main item (Brandão-Gonçalves et al., 2010). Studying a flood area in the Paraná River, Santana-Porto and Andrian (2009) found that the diet of the H. marginatus species consisted of zooplankton, especially cladocerans. According to Crippa et al. (2009), the diet of H. marginatus in marginal lagoons of the upper Paraná floodplain, mainly consisted of allochthonous items from the order Hymenoptera. According to Lowe-McConnell (1987), allochthonous food resources are very important in the stream fish diets, however autochthonous items show relevant values in various studies (Pelicice and Agostinho, 2006).

Food plasticity of young and adult $H$. marginatus and the food resources provided by the Beija-Flor stream are key factors for the high abundance of the species in the collection station of this study. The abundance, diversity and coverage of aquatic macrophytes, influenced by environmental factors such as the depth and nutrient availability (Albaret and Ecoutin, 1989), directly affect its association with the ichthyofauna. The macrophyte banks provide shelter from predators and substrate for the development of organisms that serve as food (Takeda et al., 2004) for young and adult individuals. This was confirmed by the constant presence of pupae and nymphs of Ephemeroptera, Diptera, Trichoptera, Chironomidae larvae, Cladocera, Conchostraca, and other arthropods found in the diet of H. marginatus specimens collected in the Beija-Flor stream. In addition to this rich macroinvertebrate fauna, there is micro-algae, fungi and the bacterial community, which are associated with these habitats (Pompeo and Moschini-Carlos, 2003).

The allochthonous food sources are extremely important for the ichthyofauna streams, as these resources can be a direct source of food for fish (such as terrestrial insects) and contribute to the increase in the amount of particulate organic matter that serves as food for benthic invertebrates, which in turn feed the fish. Therefore, allochthonous food resources are considered to be the basis of the food chain in streams because they are primary sources of nutrients which come from riparian vegetation (Bretschko and Waidbacher, 2001). According to Uieda and Motta (2007), the incorporation of allochthonous material in the structure of stream communities strengthens the link between aquatic and terrestrial environments. Hemigrammus marginatus is an example of a species among others that are part of this connection, since the ingested nutrients from terrestrial insects are incorporated by the fish and transformed into nutrients to be included in the system. These nutrients incorporated by the system are used as a source of energy for aquatic insects that serve as food for most fish species of the Beija-Flor stream. The high consumption of terrestrial insects of the order Hymenoptera in the Beija-Flor stream may be associated with the conservation of the riparian vegetation in its surroundings. Thus, the relative importance of allochthonous or autochthonous food in stream fish communities depends on the specific environmental conditions of each region studied, such as the presence of riparian vegetation in the basin, transparency and water current, among others (Esteves and Aranha, 1999; Luz-Agostinho et al., 2006; Abilhoa et al., 2010).

The riparian forest is a major source of food resources for ichthyofauna in preserved ecosystems (Borba et al., 2008). According to Ferreira et al. (2012a), the species Astyanax altiparanae consumed allochthonous resources in streams of the Corumbataí river basin with the presence of riparian vegetation, however in streams where the grassland was predominantly in the riparian zone, autochthonous resources prevailed in the diet of the species.

Removing riparian vegetation influences the structure of stream fish assemblages and can change them (Ferreira et al., 2012a). Preserving and restoring native riparian vegetation is the key to preserving small characins in streams (Ferreira et al., 2012b). Although the Jataí Ecological Station remains conserved, there are many environmental problems associated with the land use of its surroundings, such as fragmentation and loss of habitats in the landscape, sand mining using drainage in the Mogi-Guaçu river (Pires and Santos, 1996) and also organic and industrial loads from approximately 39 cities in the region received by the Mogi Guaçu river (Cetesb, 1991). Therefore, removing riparian vegetation can be 
one of the most harmful changes to the Beija-Flor stream and its relations with the ecosystem.

The conservation state of the Beija-Flor stream associated with the flexibility in food use, and the wide availability of food resources provided by aquatic macrophytes and riparian vegetation in the environment are key factors for the establishment and high abundance of $H$. marginatus in the collection stations studied. According to Ferreira et al. (2012b), the conservation of aquatic ecosystems and riparian vegetation are important because they provide the allochthonous resources required for the maintenance of autochthonous food chains. Therefore, maintaining riparian forests of the Beija-Flor Stream is important for the survival of $H$. marginatus in the Beija-Flor stream.

\section{Acknowledgements}

We are grateful for the financial support from CNPQ National Council of Scientific and Technological Development (process no.472136/2011-9), and Francisco Langeani Neto (UNESP) by the fish identification.

\section{References}

ABELHA, M.C.F., AGOSTINHO, A.A. and GOULART, E., 2001. Plasticidade trófica em peixes de água doce. Acta Scientiarum. Biological Sciences, vol. 23, no. 2, pp. 425-434.

ABILHOA, V., DUBOC, L.F. and AZEVEDO-FILHO, D.P., 2008. A comunidade de peixes de um riacho de Floresta com Araucária, alto rio Iguaçu, sul do Brasil. Revista Brasileira de Zoologia, vol. 25, no. 2, pp. 238-246. http://dx.doi.org/10.1590/ S0101-81752008000200012.

ABILHOA, V., VITULE, J.R.S. and BORNATOWSKI, H., 2010. Feeding ecology of Rivulus luelingi (Aplocheiloidei: Rivulidae) in a Coastal Atlantic Rainforest stream, southern Brazil. Neotropical Ichthyology, vol. 8, no. 4, pp. 813-818. http://dx.doi.org/10.1590/ S1679-62252010005000012.

AGOSTINHO, A.A., JÚLIO JUNIOR, H.F., GOMES, L.C., BINI, M. and AGOSTINHO, C.S., 1997. Composição, abundância e distribuição espaço-temporal da ictiofauna. In: A.E.A.M. VAZZOLER, A.A. AGOSTINHO and N.S. HAHN, eds. A planície de inundação do alto rio Paraná: aspectos físicos, biológicos e socioeconômicos. Maringá: Eduem, pp. 179-208.

AGOSTINHO, C S., MARQUES, E.E., OLIVEIRA, R.J. and BRAZ, P.S., 2009. Feeding ecology of Pterodoras granulosus (Siluriformes, Doradidae) in the Lajeado Reservoir, Tocantins, Brazil. Iheringia. Série Zoologia, vol. 99, no. 3, pp. 301-306.

ALBARET, J.J. and ECOUTIN, J.M., 1989. Communication mer-lagune: impact d'une réouverture sur l'ichtyofaune de la lagune Ébrié (Côte d'Ivoire). Revue d'Hydrobiologie Tropicale, vol. 22 , pp. 71-81.

BONATO, K.O. and FIALHO, C.B., 2014. Evidence of niche partitioning under ontogenetic influences among three morphologically similar Siluriformes in small subtropical streams. PLoS One, vol. 9, no. 10, pp. e110999. http://dx.doi.org/10.1371/journal. pone.0110999. PMid:25340614.

BORBA, C.S., FUGI, R., AGOSTINHO, A.A. and NOVAKOWSKI, G.C., 2008. Dieta de Astyanax asuncionensis (Characiformes,
Characidae), em riachos da bacia do rio Cuiaba, Estado do Mato Grosso. Acta Scientiarum Biological Sciences, vol. 30, no. 1, pp. $39-45$

BRANDÃO-GONÇALVES, L., OLIVEIRA, S.A. and LIMAJUNIOR, S.E., 2010. Hábitos alimentares da ictiofauna do córrego Franco, Mato Grosso do Sul, Brasil. Biota Neotropica, vol. 10, no. 2, pp. 21-30. http://dx.doi.org/10.1590/S1676-06032010000200001.

BRETSCHKO, G. and WAIDBACHER, H., 2001. Riparian ecotones, invertebrates and fish: life cycle timing and trophic base. Ecohydrology \& Hydrobiology, vol. 1, pp. 57-64.

CASATTI, L. and CASTRO, R.M.C., 1998. A fish community of the São Francisco River headwaters riffles, Southeastern Brazil. Ichthyological Exploration of Freshwaters, vol. 9, no. 3, pp. 229-242.

CASATTI, L., MENDES, H.F. and FERREIRA, K.M., 2003. Aquatic macrophytes as feeding site for small fishes in the Rosana Reservoir, Paranapanema River, Southeastern Brazil. Brazilian Journal of Biology $=$ Revista Brasileira de Biologia, vol. 63, no. 2, pp. 213-222. http://dx.doi.org/10.1590/S151969842003000200006. PMid:14509843.

CASSEMIRO, F.A.S., RANGEL, T.F.L.V.B., PELICICE, F.M. and HAHN, N.S., 2008. Allometric and ontogenetic patterns related to feeding of a neotropical fish, Satanoperca pappaterra (Perciformes, Cichlidae). Ecology Freshwater Fish, vol. 17, no. 1, pp. 155-164. http://dx.doi.org/10.1111/j.1600-0633.2007.00270.x.

COMPANHIA DE TECNOLOGIA DE SANEAMENTO AMBIENTAL - CETESB, 1991. Relatório de qualidade das águas interiores do Estado de São Paulo. São Paulo. 164 p.

CRIPPA, V.E.L, HAHN, N.S. and FUGI, R., 2009. Food resource used by small-sized fish in macrophyte patches in ponds of the upper Parana River floodplain. Acta Scientiarum. Biological Sciences, vol. 31, no. 2, pp. 119-125. http://dx.doi.org/10.4025/ actascibiolsci.v31i2.3266.

DELARIVA, R.L., AGOSTINHO, A.A., NAKATANI, K. and BAUMGARTNER, G., 1994. Ichthyofauna associated to aquatic macrophytes in the upper Parana River floodplain. Revista Unimar, vol. 16 , no. 3 , pp. 41-60.

ESTEVES, K.E. and ARANHA, J.M.R., 1999. Ecologia trófica de peixes de riacho. In: E.P. CARAMASCHI, R. MAZZONI and P.R. PERES-NETO. Ecologia de peixes de riachos. Rio de Janeiro: PPGE-UFRJ. 260 p. Série Oecologia Brasiliensis, vol. 6.

FERREIRA, A., GERHARD, P. and CYRINO, J.E.P., $2012 \mathrm{~b}$. Diet of Astyanax paranae (Characidade) in streams with different riparian land covers in the Passa-Cinco River basin, southeastern Brazil. Iheringia. Série Zoologia, vol. 102, no. 1, pp. 80-87.

FERREIRA, A., PAULA, F.R.P., FERRAZ, S.F.B., GERHARD, P. and KASHIWAQUI, E.A.L., 2012a. Riparian coverage affects diets of characids in neotropical streams. Ecology Freshwater Fish, vol. 21, no. 1, pp. 12-22. http://dx.doi.org/10.1111/j.16000633.2011.00518.x.

GRACIOLLI, G., AZEVEDO, M.A. and MELO, F.A.G., 2003. Comparative study of the diet of Glandulocaudinae and Tetragonopterinae (Ostariophysi: Characidae) in a small stream in Southern Brazil. Studies on Neotropical Fauna and Environment, vol. 38, no. 2, pp. 95-103. http://dx.doi.org/10.1076/ snfe.38.2.95.15932.

HAHN, N.S., PAVANELLI, C.S. and OKADA, E.K., 2000. Dental development and ontogenetic diet shifts of Roeboides paranensis Pignalberi (Osteichthyes, Characinae) in pools of the upper Rio 
Paraná. Revista Brasileira de Biologia $=$ Brazilian Journal of Biology, vol. 60, no. 1, pp. 93-99. http://dx.doi.org/10.1590/ S0034-71082000000100012. PMid:10838928.

HYNES, H.B.N., 1950. The food of freshwater sticklebacks (Gasterosteus aculeatus and Pygosteus pungitius) with a review of methods used in studies of the food fishes. Journal of Animal Ecology, vol. 19, no. 1, pp. 36-57. http://dx.doi.org/10.2307/1570.

HYSLOP, E.J., 1980. Stomach content analysis - a review of methods and their application. Journal of Fish Biology, vol. 17, no. 4, pp. 411-429. http://dx.doi.org/10.1111/j.1095-8649.1980. tb02775.x.

KAWAKAMI, E. and VAZZOLER, G., 1980. Método gráfico e estimativa de índice alimentar aplicado no estudo de alimentação de peixes. Boletim do Instituto Oceanográfico, vol. 29, no. 2, pp. 205-207. http://dx.doi.org/10.1590/S0373-55241980000200043.

KOROLEFF, F., 1976. Determination of nutrients. In: K. GRASSHOFF, ed. Methods of seawater analysis. New York: Verlag Chemie Weinhein, pp. 117-181.

LEGENDRE, L. and LEGENDRE, P., 2012. Numerical ecology. 3rd ed. Amsterdan: Elsevier Scientific Publishing Company, pp. 1006, vol. 24.

LIMA, D.O. and BEHR, E.R., 2010. Feeding ecology of Pachyurus bonariensis Steindachner, 1879 (Sciaenidae: Perciformes) in the Ibicui River, Southern Brazil: ontogenetic, seasonal and spatial variations. Brazilian Journal of Biology = Revista Brasileira de Biologia, vol. 70, no. 3, pp. 503-509. http://dx.doi.org/10.1590/ S1519-69842010000300006. PMid:20730336.

LIMA-JUNIOR, S.E. and GOITEIN, R., 2003. Ontogenetic diet shifts of a Neotropical catfish, Pimelodus maculatus (Siluriformes, Pimelodidae): an ecomorphological approach. Environmental Biology of Fishes, vol. 68, no. 1, pp. 73-79. http://dx.doi. org/10.1023/A:1026079011647.

LIMA, F.C.T., MALABARBA, L.R., BUCKUP, P.A., PEZZI DA SILVA, J.F., VARI, R.P., HAROLD, A., BENINE, R., OYAKAWA, O.T., PAVANELLI, C.S., MENEZES, N.A., LUCENA, C.A.S., MALABARBA, M.C.S.L., LUCENA, Z.M.S., REIS, R.E., LANGEANI, F., CASSATI, L. and BERTACO, V.A., 2003. Genera incertae sedis in Characidae. In: R.E. Reis, S.O. KULLANDER and C.J. FERRARIS-JUNIOR, eds. Checklist of the freshwater fishes of South and Central America. Porto Alegre: Edipucrs, pp. 106-168.

LOWE-MCCONNELL, R.H., 1987. Ecological studies in tropical fish communities. London: Cambridge University Press, 382 p.

LUZ-AGOSTINHO, K.D.G., BINI, L.M., FUGI, R., AGOSTINHO, A.A. and JÚLIO-JUNIOR, H.F., 2006. Food spectrum and trophic structure of the icthyofauna of Corumbá reservoir, Paraná River Basin, Brazil. Neotropical Ichthyology, vol. 4, no. 1, pp. 61-68. http://dx.doi.org/10.1590/S1679-62252006000100005.

MACKERETH, F.J.H., HERON, J. and TALLING, J.F., 1978. Waters analysis: some revised methods for limnologists. Kendall: Titus Wilson \& Son Ltd./Freshwater Biological Association Scientific Publication. 117 p. no. 36.

MAZZONI, R. and COSTA, L.D.S., 2007. Feeding ecology of stream-dwelling fishes from a Coastal Stream in the Southeast of Brazil. Brazilian Archives of Biology and Technology, vol. 50, no. 4, pp. 627-635. http://dx.doi.org/10.1590/S1516-89132007000400008.

MAZZONI, R., NERY, L.L. and IGLESIAS-RIOS, R., 2010. Ecologia e ontogenia da alimentação de Astyanax janeiroensis (Osteichthyes, Characidae) de um riacho costeiro do Sudeste do
Brasil. Biota Neotropica, vol. 10, no. 3, pp. 53-60. http://dx.doi. org/10.1590/S1676-06032010000300005.

MURPHY, J. and RILEY, J.P., 1962. A modified single solution method for the determination of phosphate in natural waters. Analytica Chimica Acta, vol. 27, pp. 31-36. http://dx.doi. org/10.1016/S0003-2670(00)88444-5.

PELICICE, F.M. and AGOSTINHO, A.A., 2006. Feeding ecology of fishes associated with Egeria spp. patches in a tropical reservoir, Brazil. Ecology Freshwater Fish, vol. 15, no. 1, pp. 10-19. http:// dx.doi.org/10.1111/j.1600-0633.2005.00121.x.

PELICICE, F.M., AGOSTINHO, A.A. and THOMAZ, S.M., 2005. Fish assemblages associated with Egeria in a tropical reservoir: investigating the effects of plant biomass and diel period. Acta Oecologica, vol. 27, no. 1, pp. 9-16. http://dx.doi.org/10.1016/j. actao.2004.08.004.

PIRES, A.M.Z.C.R., 1994. Elaboração de um banco de dados digitais georeferenciados como subsídio ao planejamento e manejo de uma unidade de conservação - Estação Ecológica de Jataí (Luiz Antônio, São Paulo), 68 p. São Carlos: Universidade Federal de São Carlos. Dissertação de Mestrado em Ecologia e Recursos Naturais

PIRES, J.S.R. and SANTOS, J.E., 1996. Preliminary analysis of environmental impacts applied to a rural area of Sao Paulo State (Luiz Antônio, SP, Brazil). Fargo: International Association for Impact Assessment, pp. 969-974, vol. 2.

POMPÊO, M.L.M. and MOSCHINI-CARLOS, V., 2003. Macrófitas aquáticas e perifiton, aspectos ecológicos e metodológicos. São Carlos: RiMa. 124 p.

RODRIGUES, M.H., 1997. Estudo da fauna de Chironomidae (Diptera) do sedimento na represa do Beija-Flor, na Estação Ecológica de Jataí, Luiz Antonio, SP, 85 p. São Carlos: Universidade Federal de São Carlos. Dissertação de Mestrado em Ecologia e Recursos Naturais.

ROZAS, L.P. and ODUM, W.E., 1988. Occupation of submerged aquatic vegetation by fishes: testing the roles of food and refuge. Oecologia, vol. 77, no. 1, pp. 101-106. http://dx.doi.org/10.1007/ BF00380932.

REIS, R.O., KULLANDER, S.O. and FERRARIS-JUNIOR, C.J., 2005. Check list of the freshwater fishes of South and Central America. Porto Alegre: Edipucrs. 742 p.

SANTANA-PORTO, E.A. and ANDRIAN, I.F., 2009. Trophic organization the ichthyofauna of two semi-lentic environments in a flood plain on the upper Paraná River, Brazil. Acta Limnologica Brasiliensia, vol. 21, no. 3, pp. 359-366.

SANTOS, J.E., MOZETO, A.A., and GALETTI-JUNIOR, P.M., 1989. Caracterização preliminar da Estação Ecológica de Jataí (Luiz Antonio, SP). Lagoas marginais do rio Mogi-Guaçu: avaliação ambiental e papel ecológico. São Carlos: UFSCar/ CENA/USP/ESALQ/USP/UNESP. 50 p. Projeto de pesquisa multidisciplinar e interinstitucional.

SATO, Y. and GODINHO, H.P., 1988. A questão do tamanho de primeira maturação dos peixes de Três Marias, MG. In: ASSOCIAÇÃO MINEIRA DE AQUICULTURA, ed. Coletânea de resumos dos encontros da Associação Mineira de Aquicultura (AMA): 1982-1987. Brasília: CODEVASF, pp. 93-94.

SÚAREZ, Y.R., VALÉRIO, S.B., TONDALO, K.K., XIMENES, L.Q.L. and FELIPE, T.R.A., 2007. Determinantes ambientais da ocorrência de espécies de peixes em riachos de cabeceira da bacia do rio Ivinhema, alto rio Paraná. Acta Scientiarum Biological 
Sciences, vol. 29, no. 2, pp. 145-150. http://dx.doi.org/10.4025/ actascibiolsci.v29i2.520.

SUIBERTO, M.R., GALUCH, A.V., BIALETZKI, A. and NAKATANI, K., 2009. Ontogenetic shifts in the digestive tube and diet of Bryconamericus stramineus Eigenmann, 1908 (Osteichthyes, Characidae). Acta Limnologica Brasiliensia, vol. 21, no. 4, pp. 465-472.

TABACHNICK, B. and FIDELL, L., 1996. Using multivariate statistics. 3rd ed. New York: Harper Collins College Publishers.

TAKEDA, A.M., FUJITA, D.S., KOMATSU, E.H., PAVAN, C.B., OLIVEIRA, D.P., ROSIN, G.C., IBARRA, J.A.A., SILVA, C.P. and ANSELMO, S.F., 2004. Influence of environmental heterogeneity and water level on distribution of zoobenthos in the Upper Parana River (Baia and Parana Rivers). In: A.A. AGOSTINHO, L. RODRIGUES, L.C. GOMES, S.M. THOMAZ and L.E. MIRANDA. Structure and functioning of the Parana River and its floodplain. Maringá: Eduem. pp. 91-95.

THOMAS, R.J., KING, T.A., FORSHAW, H.E., MARPLES, N.M., SPEED, M.P. and CABLE, J., 2010. The response of fish to novel prey: Evidence that dietary conservatism is not restricted to birds. Behavioral Ecology, vol. 21, no. 4, pp. 669-675. http:// dx.doi.org/10.1093/beheco/arq037.

UIEDA, V.S. and MOTTA, R.L., 2007. Trophic organization and food web structure on southeastern Brazilian streams: a review. Acta Limnologica Brasiliensia, vol. 19, no. 1, pp. 15-30.

VITULE, J.R.S., BRAGA, M.R. and ARANHA, J.M.R., 2008. Ontogenetic, spatial and temporal variations in the feeding ecology of Deuterodon langei Travassos, 1957 (Teleostei: Characidae) in a Neotropical stream from the Atlantic rainforest, southern Brazil. Neotropical Ichthyology, vol. 6, no. 2, pp. 211-222. http://dx.doi. org/10.1590/S1679-62252008000200008.

WETZEL, R.G. and LIKENS, G.E., 2005. Limnological analyses. 3rd ed. New York: Springer-Verlag. 430 p.

WOOTTON, R.J., 1992. Fish ecology. New York: Chapman \& Hall. 212 p.

WOOTTON, R.J., 1998. Ecology of teleost fishes. London: Kluwer Academic Publishers, pp. 386. Fish and Fisheries Series, vol. 24. 